\title{
Pedagogy for Autonomy in FLT: An Exploratory Analysis on its Implementation through Case Studies
}

\author{
Borja Manzano VÁzQuez \\ Universidad de Granada
}

Received: 19 October 2013 / Accepted: 23 March 2014

ISNN: $1697-7467$

\begin{abstract}
Through different case studies, this paper analyses the teaching practice of six foreign language teachers to investigate whether learner autonomy is a relevant goal in foreign language teaching and how the concept of pedagogy for autonomy is implemented regarding the pedagogical principles proposed by Jiménez Raya et al. (2007). The main conclusion to be drawn from this research is that there is a striking lack of learner autonomy in the context of foreign language learning. The pedagogical principles for the development of pedagogy for autonomy are marginally implemented as in most cases classroom practice is still dominated by a traditional, teacher-centred approach to language learning.

Keywords: Foreign language teaching, learner autonomy, pedagogy for autonomy
\end{abstract}

Pedagogía para la autonomía en la enseñanza de lenguas extranjeras: Un análisis exploratorio sobre su implementación mediante estudios de caso

RESUMEN: Mediante diferentes estudios de caso, analizamos la práctica docente de seis profesores de lengua extranjera para investigar si la autonomía del aprendiz es un objetivo relevante en la enseñanza de lenguas extranjeras y cómo el concepto de una pedagogía para la autonomía es implementado en relación a los principios pedagógicos propuestos por Jiménez Raya et al. (2007). La principal conclusión de este estudio es que la autonomía del aprendiz dista de ser un objetivo educativo relevante en el contexto del aprendizaje de lenguas extranjeras. Los principios pedagógicos para el desarrollo de una pedagogía para la autonomía son ligeramente implementados ya que en muchos casos la práctica en el aula está dominada por un enfoque tradicional, centrado en el profesor.

Palabras clave: Enseñanza de lenguas extranjeras, autonomía del aprendiz, pedagogía para la autonomía

\section{INTRODUCTION}

The development of learner autonomy, i.e. "the ability to take charge of one's own learning" (Holec, 1981: 3), figures as one of the most important educational goals in discussion of language teaching education over the last decades (Aviram, 1993; Benson, 2011; Jiménez Raya, 2008, 2009; Jiménez Raya, Lamb and Vieira, 2007; Little, 2007; Morgan, 1996). Notions such as education for life, education for lifelong learning and education for democratic citizenship have become increasingly prominent in educational rhetoric, promp- 
ting the growing need for implementing principles favouring pedagogy for autonomy in the modern language classroom (Lamb, 2008).

Learner autonomy has been identified as one of the key competences for lifelong learning (European Commission, 2006). To be effective citizens in the knowledge-based society of the $21^{\text {st }}$ century, learners will be more and more forced to rely on their own resources. Learners will constantly need to learn new things, apply their knowledge in new contexts and be capable of adapting themselves to the new demands of a rapidly changing world. In this sense teaching cannot be exclusively focused upon transmitting concepts and principles, but needs to help learners develop capacities such as creativity, critical thinking, social responsibility, decision-making and problem-solving skills. For this purpose, the notion of learner autonomy aims at providing pupils with the knowledge and skills needed for permanent education and self-directed learning.

Despite the general agreement on the importance of autonomy as an educational goal and the positive results obtained from implementing pedagogy for autonomy in modern language teaching practice (see Dam, 1995; Dam and Legenhausen, 1996, 2010; Legenhausen, 2003; Magno e Silva, 2008; Serrano Sampedro, 2008; Trebbi et al., 2008), learner autonomy still appears alien to the foreign language classroom (Jiménez Raya, 2011; Jiménez Raya et al., 2007), remaining in most cases at a theoretical level. As Jiménez Raya (2011) notes, the centrality of learner autonomy in the current teaching practice is pervaded by "a culture of double talk", that is, a discrepancy between what the theory says it should be done and what is actually done in the classroom. Through the analysis of different case studies, the major aim of the present study is to explore whether this divorce between theory and practice is true of language classrooms nowadays. In doing so, we will analyse a small sample of the Spanish educational context to determine whether learner autonomy is a relevant educational goal in the practice of FLT and what principles for pedagogy for autonomy are implemented.

\section{Pedagogy for autonomy}

Autonomy, as Holec (1981: 3) noted, is not an inborn capacity "but must be acquired either by 'natural' means or (as most often happens) by formal learning, i.e. in a systematic, deliberate way". Pedagogy for autonomy aims at facilitating an approximation of the learner to the learning process and content by giving him/her the opportunity to assume greater responsibility for learning, and acknowledging him/her as a crucial participant in the management of this learning. Pedagogy for autonomy is defined as:

the conscious and deliberately organized implementation of the possibility for learners to set their learning objectives, to establish the procedures and methods for learning, to monitor their progress and to self-evaluate the learning process and outcomes (Camilleri Grima, 2007: 83)

Jiménez Raya (2008) argues that pedagogy for autonomy is the pedagogical realization of a view of education as transformation and empowerment. Autonomy in the educational context is associated with "a radical restructuring of our whole conception of language pedagogy, a restructuring that involves the rejection of the traditional classroom and the 
introduction of wholly new ways of working" (Allwright, 1988: 35). Fostering learner autonomy in the foreign language classroom requires a process of change whereby we move from a teacher-centred approach to language learning to a more learner-centred approach. In this sense, the concept of pedagogy for autonomy can be interpreted as teachers using their power to empower students. Learners are allowed to take control of their own linguistic and learner development in a transition from teacher-control to learner-control (Jiménez Raya and Pérez Fernández, 2002). The teacher makes learners increasingly responsible for their learning through a gradual process of negotiation and transfer of certain duties to students such as setting their learning goals, selecting their materials, or determining the pacing of their learning, among others.

\subsection{Implementing pedagogy for autonomy}

Pedagogy for autonomy is an educational process that may take diverse forms for different teachers, depending on the teacher's understanding of the teaching and learning process and students' interests and abilities. In fact, different theoretical frameworks have been developed in the specialised literature to encourage the development of learner autonomy in language education (see, for example, Benson, 2011; Little, 2007; Littlewood, 1997, 2002; Macaro, 1997; Nunan, 1997; Smith, 2003). In our case, we will analyse the implementation of pedagogy for autonomy in the foreign language classroom using the theoretical framework proposed by Jiménez Raya et al. (2007: 58), which we consider to be the most comprehensive proposal to date. This framework encompasses the following nine pedagogical principles:

1. Encouraging responsibility, choice, and flexible control

2. Providing opportunities for learning to learn and self-regulation

3. Creating opportunities for cognitive autonomy support

4. Creating opportunities for integration and explicitness

5. Developing intrinsic motivation

6. Accepting and providing for learner differentiation

7. Encouraging action-orientedness

8. Fostering conversational interaction

9. Promoting reflective inquiry ${ }^{l}$

\section{RESEARCh QUESTIONS}

The nature of this study is primarily exploratory, that is to say, we want to examine whether the notion of learner autonomy is an educational goal in the context of FLT and what principles for pedagogy for autonomy are promoted in the classroom. To this end, the study aims at giving an answer to the following research questions:

Is learner autonomy a relevant educational goal in the practice of FLT?

How is the concept of pedagogy for autonomy implemented in the context of FLT?

\footnotetext{
${ }^{1}$ For more details see Jiménez Raya et al. (2007: 58-66).
} 


\section{Methodology}

\subsection{Participants and Research Contexts}

Six foreign language teachers participated in the study. Four of them were secondary school teachers who taught English from grade 7 to grade 9 at the same secondary school, whereas the other two foreign language teachers taught English and German at level A1 of the CEFR at an Official Language School (OLS) ${ }^{2}$. The main difference between both educational contexts lied in the students. Secondary school teachers taught teenage students who were at their compulsory secondary education stage. In contrast, teachers at the OLS taught both teenage and adult students. Moreover, as opposed to secondary education, enrolling ${ }^{3}$ on the course at the OLS is voluntary, so we can assume that the students who attended this school were motivated to learn the foreign language.

For our report, the six teachers have been assigned different numbers to preserve their anonymity (e.g. Teacher 1, Teacher 2, etc.). Due to different constraints such as exams or the overlap of class hours, some teachers could be observed during more classes than others. In Table 1 we detail the number of classes each teacher was observed, the grade or level of language proficiency of the class, and the language they taught in each case.

Table 1. Grade/Level of language proficiency, number of classes observed and language taught

\begin{tabular}{|c|c|c|c|}
\hline & $\begin{array}{c}\text { Grade/Level of Lan- } \\
\text { guage Proficiency }^{4}\end{array}$ & $\begin{array}{c}\text { Number of Classes } \\
\text { Observed }^{5}\end{array}$ & Language \\
\hline Teacher 1 & Grade 7 & 4 & English \\
\hline Teacher 2 & Grade 7 & 6 & English \\
\hline Teacher 3 & Grade 8 & 4 & English \\
\hline Teacher 4 & Grade 9 & 3 & German \\
\hline Teacher 5 & A1 & 2 & German/English \\
\hline Teacher 6 & A1 & 4 & \\
\hline
\end{tabular}

\footnotetext{
${ }^{2}$ Secondary education and studies at the OLS are regulated by the Organic Law 2/2006 of Education (LOE, 2006).

${ }^{3}$ The prerequisite to enter the OLS is to have completed the first cycle of compulsory secondary education, that is, grade 7 and 8 .

${ }^{4}$ Each teacher was always observed with the same group of students.

${ }^{5}$ The classes at secondary school lasted one hour. In contrast, each class at the OLS was two hours in length.
} 


\subsection{Instrument and Procedure}

The data for the study were collected through classroom observation, thus allowing us to immerse ourselves in the educational settings and learn first-hand about the teaching methodology that the different teachers implemented in the foreign language classroom. The six foreign language teachers were observed during several regular classes at the end of the third term in order to determine whether the notion of learner autonomy was fostered in the language classroom and how it was implemented. Our role as researchers was that of a complete observer (Cohen, Manion and Morrison, 2000: 457), merely taking notes about the factors being studied, sitting at the back of the classroom and being completely detached from the group. For the observation, we designed different observation grids in which each of the nine pedagogical principles for pedagogy for autonomy proposed by Jiménez Raya et al. (2007) was subsequently analyzed and divided into different sub-components or observation categories. Whenever one of these categories was (or not) put into practice in the classroom, this situation was recorded in the observation grid. In this way, we could keep a record of teachers' daily practice, facilitating the composition of cases for each teacher.

\section{CASES}

In this section we proceed to present the case studies. Due to limitations of space, we concentrate on two case studies: Teacher 4 and Teacher 6 , who represent two opposite approaches to language teaching. The structure for each case is as follows: we first report the analysis of our observation notes for the classes observed, providing the reader with a picture of the teacher's teaching practice, to conclude with a general comment on each case regarding the implementation of the pedagogical principles for pedagogy for autonomy.

\subsection{Teacher 4}

\subsubsection{Class 1}

In this first class the teacher begins a new unit. Before starting to work, the teacher and students look at the syllabus to see the main contents and objectives of the unit. However, they simply have a quick look at them without discussing the main points established and how they meet students' linguistic needs as foreign language learners. The class is then divided into two different sections: the explanation provided by the teacher and learners' individual work.

The first thing we observe is that the teacher has full control over language learning and makes all the decisions concerning classroom management, telling students what they have to do, how and when. All the classroom activities focus on the target language (i.e. language teaching activities such as gap-filling, matching, or multiple-choice) and there is no explicit work on teaching learning strategies. Students have a passive role as they only participate when they are requested to do so by the teacher. In the meanwhile, they remain silent. Great part of the lesson is conducted in Spanish and students tend to speak in their mother tongue, only doing it in English when they correct the activities. Classroom 
interactions are teacher controlled and they follow the IRF sequence (Initiation-ResponseFeedback): the teacher initiates, the learner responds and the teacher corrects him/her by providing feedback. Moreover, there is no interaction among students and no work in pairs or groups. Another important feature is learners' lack of motivation and the fact that the teacher does not try to motivate them. The class finishes with students listening to a short dialogue and repeating different sequences from that dialogue.

\subsubsection{Class 2}

The responsibility for the learning process is exclusively shouldered by the teacher. He determines what to do and how much time students have in order to complete the activities. His control is such that he even tells students what they have to study. As an example, students write words related to parts of the body on the blackboard. When the teacher is making sure that they know their meaning in Spanish, he tells them the words they must learn. This situation clearly contributes to making students teacher-dependent as they will always wait for their teacher to tell them what to study and, consequently, they will be unable to make those decisions on their own.

Most part of the lesson is devoted to the explanation and review of the passive voice through the completion of different learning activities. All the activities continue being language teaching activities focusing on grammar (i.e. the structure of the passive voice) or vocabulary related to parts of the body, and there is no work on learning to learn, learning strategies, or metacognitive knowledge. We still notice that students hardly speak in English in the classroom and they are not encouraged to do so. They have no opportunity to engage in conversational interactions among themselves since all the learning activities are done individually. As in the previous class, the lesson finishes with students listening to and repeating sequences from a dialogue.

\subsubsection{Class 3}

This third class is quite similar to the previous ones regarding classroom management: the teacher continues assuming the responsibility for learning, classroom interactions are teacher controlled, learners' work is done individually, and there is no focus on learning to learn activities or learning strategies.

On this occasion, the teacher revises the passive voice and they do an activity about this grammar tense in which students turn several sentences from the active into the passive voice. When they are checking the activity, the teacher checks the sentences rather than asking students whether they are right or wrong. He tells learners the changes produced in the passive voice instead of letting students think on their own. After doing so, they move on to a second activity which focuses on completing gaps by writing the correct adverb from the adjective given.

\subsubsection{Analysis}

In this case we have not observed any pedagogical principle for pedagogy for autonomy being implemented in the classroom. The classes are in this sense totally teacher-centred. The 
responsibility for the learning process is exclusively shouldered by the teacher. He has full control over language learning and makes all the decisions concerning classroom management. To put it simply, students have no voice in the learning process and play a passive role in the classroom, behaving like mere 'containers' to be filled with the information the teacher is dispensing. As a consequence, learners see themselves immersed in an atmosphere where they do not feel motivated to learn and become disengaged from their learning.

The lack of opportunities for learning to learn and self-regulation has been a constant during these classes. Learning strategies, metacognitive knowledge or learners' beliefs about language learning are completely ignored in the foreign language classroom. Concerning conversational interaction, students have little opportunity to use the target language and to interact among themselves since most classroom interactions are aimed at correcting learning activities, thus being teacher controlled, following the IRF sequence, and having learners contributing a few words or a sentence. Furthermore, the teacher does not provide for learner differentiation since all learners work on the same activities and learning materials.

\subsection{Teacher 6}

The first two classes belong to the teaching of German as a foreign language, whereas class 3 and 4 represent the teaching of English.

\subsubsection{Class 1}

The beginning of the lesson is devoted to working on different prepositions in German. The teacher explains their use and students complete an activity aimed at practising them. Then, the teacher introduces a rap song including the prepositions studied and learners are divided into two groups in order to sing it. The teacher encourages them to sing the song quicker than the other group, trying to motivate them to do the activity.

Next, students work on different learning activities designed to cater for learner differentiation. They are provided with a wide range of activities in which they can work on the four language skills at different levels of difficulty. Moreover, they have the opportunity to work individually, in pairs or groups. Consequently, learners are fully responsible for deciding what language skills they want to work on, at what level of difficulty, and how. In this respect, they can work at their own pace and according to their particular learning interests, needs, and abilities in the target language. Furthermore, they can assess their learning outcomes in each activity as they are provided with a grid where they write down the activities they have done, the language skills they have practised, and what they have learnt. As a result, learners' intrinsic motivation is enhanced as they come to feel responsible for their learning. Students experience a sense of personal agency and self-determination since they take control over their learning, make decisions on learning activities, and evaluate their learning process.

\subsubsection{Class 2}

The lesson begins with the revision of vocabulary students have learnt in previous classes. They are provided with flashcards containing objects whose features and utility they have to 
describe to their classmates. By working in pairs, we observe that learners help and correct each other, developing a capacity to learn in cooperation with others. The teacher creates a learning community in which responsibility for one's own and each other's learning is shared.

Next, the teacher decides to revise the prepositions they studied in the previous class. She uses realia such as a pen and a pencil case to ask students different questions about the position of these objects, making learners take an active part in the explanation. After this, students complete a gap-filling activity from their textbook which helps them reinforce the teacher's explanation. Rather than controlling the correction of the activity, the teacher displays the solutions on the screen and lets students correct it on their own.

Now, they move on to practise the following function: asking for and giving directions. The teacher places different buildings (e.g. a library, a bus station, etc.) drawn on cards around the classroom. In pairs, students first give instructions to their classmate to guide him/her to one of those places, and later they ask each other how they can get to a specific building. As we can see, learners are constantly given opportunities to interact and communicate among themselves. Finally, students work on a reading activity. In groups of three students, they read several recipes in German and match them to their right picture. The main problem is that learners are not told about the reading strategies they can use to complete the activity, for instance, scanning (i.e. looking for specific information such as the ingredients).

\subsubsection{Class 3}

This class is aimed at providing for learner differentiation. Learners have different 'learning stops' in the classroom representing a wide variety of learning activities they can choose to practise what they have learnt during the year, for example, tenses, linking words, or functions such as giving directions. Here there is an example of a learning activity:

\begin{tabular}{|c|c|c|c|c|c|}
\hline Stop 21 & $\begin{array}{c}\text { What to } \\
\text { learn }\end{array}$ & Material & Correction & Time & Difficulty \\
\hline $\begin{array}{c}\text { Town } \\
\text { game }\end{array}$ & $\begin{array}{c}\text { Ask your } \\
\text { partner how } \\
\text { to get to } \\
\text { different } \\
\text { places }\end{array}$ & $\begin{array}{c}\text { Question } \\
\text { and answer } \\
\text { cards }\end{array}$ & $\begin{array}{c}\text { Solutions at } \\
\text { the back }\end{array}$ & 15 & Intermediate \\
\hline
\end{tabular}

The teacher explains what learners have to do and tells them they have the whole lesson to work on these learning activities. As in class 1, learners are given complete freedom to choose the activities they want to do. They can work according to their learning interests, needs, and abilities in the target language. They can determine the pacing of their learning and the activities allow them to work individually, in pairs or groups. The activities also include a section on self-assessment where students can assess their learning outcomes in each activity. They have a sheet of paper where they write down the activities they have done, what they have learnt, how they evaluate the activity, and they have to give themselves a mark and explain why they have given themselves such a mark. 
The result is extremely positive concerning learners' affective component. The teacher creates an atmosphere where learners feel motivated to learn and work. Their intrinsic motivation is enhanced as they feel they can take responsibility for and control over their learning rather than being constantly commanded by the teacher. Furthermore, they develop a positive attitude towards learning and the language since they can learn while enjoying what they are doing.

\subsubsection{Class 4}

In this class, students basically work on grammar and speaking. The main topic of the lesson is 'booking holidays'. Students listen to a short dialogue in which they have to identify the speakers' plans for their holidays. Then, they discuss the activity with the teacher and move on to the explanation of the grammatical structure on going to. While students are doing an activity on this tense, the teacher writes on the blackboard what they will do next: 1) look at the pictures and imagine those are your holidays and 2) talk about what you are going to do. In pairs, students have different pictures they use to discuss what they will do on their holidays.

Next, each student reads a text and talks to his/her classmate about the holidays they have read. After this, they write five sentences using 'going to' about their dream holidays and then they move around the classroom looking for classmates to tell them the holidays they have planned. As we can see, the teacher involves exchange and participation from all students. The last part of the lesson is devoted to work on there is, there are and vocabulary related to food.

\subsubsection{Analysis}

Most principles for the development of pedagogy for autonomy are implemented in this case. The teacher fosters flexible control by allowing learners to exercise different levels of control at different moments of the learning process. She moves from classes where she directs students' actions in the classroom to lessons where learners can have full control over learning, working at their own pace and according to their particular learning interests and needs in the language. As has been noted in class 1 and class 3, the teacher provides learners with a wide range of activities and they are fully responsible for deciding what learning activities they want to do, what language skills they want to work on, at what level of difficulty, and how they want to work, i.e. individually, in pairs or groups. In this way, the teacher provides for learner differentiation. Besides, learners work in an atmosphere where they feel motivated to learn. By giving them the opportunity to take responsibility for their learning, the teacher fosters a feeling of joint control and personal involvement. Learners take a pro-active role in their learning process and experience agency and self-determination, thereby encouraging action-orientedness.

Another characteristic of these classes has been the emphasis on the importance of a communicative approach on the part of the learner to the development of learner autonomy. Learners are constantly given opportunities to use the target language in the classroom and communicate among themselves through pair and group work. During these classes, however, there has been no explicit focus on learning to learn, self-regulation, cognitive autonomy support, or reflective inquiry. 


\section{Discussion}

As stated in the national curriculum (LOE, 2006), one of the main objectives of education in Spain is to develop entrepreneurship and self-confidence, participation, critical awareness, personal initiative and the capacity to learn how to learn, plan, make decisions, and assume responsibility. However, the findings of this research suggest that the practice in the educational context differs considerably from what the official curriculum states that should be done.

The first research question addressed in this study asked whether learner autonomy is a relevant educational goal in the practice of FLT. With the exception of the OLS, we can conclude that the notion of learner autonomy is not a relevant educational goal in the great majority of the cases studied. On the whole we have observed that teachers do not foster learner autonomy in the foreign language classroom and in secondary education the pedagogical principles for the development of pedagogy for autonomy are marginally implemented. Regarding the above-mentioned objective of the national curriculum (LOE, 2006), learners have no opportunity to develop any capacity for personal initiative in their learning as they are not made responsible for decision-making and planning, monitoring or evaluating their learning process. Despite being included in the national curriculum as a basic competence for lifelong learning, learning how to learn is not a relevant goal in the foreign language classroom. In this respect, learners are not provided with learning strategies that could help them manage their own learning and teachers normally do not develop learners' awareness of themselves as language learners.

Table 2. Pedagogical principles for pedagogy for autonomy in the case studies

\begin{tabular}{|l|c|c|c|c|c|c|}
\hline & $\begin{array}{c}\text { Teacher } \\
1\end{array}$ & $\begin{array}{c}\text { Teacher } \\
2\end{array}$ & $\begin{array}{c}\text { Teacher } \\
3\end{array}$ & $\begin{array}{c}\text { Teacher } \\
4\end{array}$ & $\begin{array}{c}\text { Teacher } \\
5\end{array}$ & $\begin{array}{c}\text { Teacher } \\
6\end{array}$ \\
\hline $\begin{array}{l}\text { Encouraging responsibility, } \\
\text { choice, and flexible control }\end{array}$ & & & & & & \\
\hline $\begin{array}{l}\text { Providing opportunities for } \\
\text { learning to learn and self- } \\
\text { regulation }\end{array}$ & $\checkmark$ & & & & & \\
\hline $\begin{array}{l}\text { Creating opportunities for } \\
\text { cognitive autonomy support }\end{array}$ & $\checkmark$ & & $\checkmark$ & & & \\
\hline $\begin{array}{l}\text { Creating opportunities for } \\
\text { integration and explicitness }\end{array}$ & & & & & $\checkmark$ & $\checkmark$ \\
\hline $\begin{array}{l}\text { Developing intrinsic } \\
\text { motivation }\end{array}$ & $\checkmark$ & & & & & $\checkmark$ \\
\hline $\begin{array}{l}\text { Accepting and providing for } \\
\text { learner differentiation }\end{array}$ & & & & & & $\checkmark$ \\
\hline $\begin{array}{l}\text { Encouraging action- } \\
\text { orientedness }\end{array}$ & & & & & $\checkmark$ & $\checkmark$ \\
\hline $\begin{array}{l}\text { Fostering conversational } \\
\text { interaction }\end{array}$ & $\checkmark$ & $\checkmark$ & & & & $\checkmark$ \\
\hline Promoting reflective inquiry & $\checkmark$ & $\checkmark$ & & & & $\checkmark$ \\
\hline
\end{tabular}


With regard to the second research question, the implementation of the pedagogical principles for the development of pedagogy for autonomy varies considerably depending on the case (see Table 2). As has been noted, one of the premises defining the concept of learner autonomy is encouraging learners to assume increasing responsibility for their learning process and develop a pro-active role in making decisions concerned with learning (Camilleri Grima, 2007; Jiménez Raya et al., 2007). Nevertheless, except for the last case (i.e. Teacher 6), we have observed that the responsibility for learning and decision-making rests with the teacher alone. Teachers have full control over learning when determining the learning content, setting the learning objectives, choosing learning methods, and selecting learning materials and activities. These educational contexts resemble traditional approaches to language learning in which the learner's self as a learner is constructed by others, in this case, the teacher. Learners have no voice in deciding what to learn and how to learn it, but they simply do what the teacher tells them to do. In other words, democratic principles like voice, freedom and choice, identified by Marsh, Richards and Smith (2001), appear alien to the foreign language classroom and, consequently, learners feel alienated from the learning process.

The only exception to this tendency is Teacher 6 who develops the notion of flexible control (Aviram and Yonah, 2004), allowing learners to move from states of no control to states of full control over learning according to the circumstances. There are classes in which learners depend on the teacher's instructions and others in which, as discussed by Jiménez Raya and Pérez Fernández (2002), the teacher makes learners increasingly responsible for their learning through a gradual transfer of certain duties to them such as selecting their learning activities, determining the pacing of their learning, or evaluating their learning outcomes.

In the great majority of cases, teachers do not provide opportunities for learning to learn and self-regulation. Reflecting upon the learning process or raising learners' awareness of themselves as language learners is not fostered in the foreign language classroom. Learners learn to use the target language but they do not learn how to learn it. Teachers focus on teaching grammar, vocabulary or the language skills rather than teaching learners how to exert control over their learning processes. Only Teacher 2 provides learners with opportunities to reflect on their learning process. By encouraging learners to revise and discuss their learning objectives, they can reflect on their own progress and engage in a process of self-evaluation by which they become aware of their strengths and weaknesses in the target language. In this way, they can plan and accommodate future work to the accomplishment of those learning goals they still need to achieve.

Learning strategies are an essential component of learning to learn. Appropriate use of learning strategies can enable students to become more independent, autonomous, lifelong learners, hence the need for an informed approach to training ${ }^{4}$ in strategy use (Wenden, 1986). Surprisingly, we have observed that learning strategies are completely ignored in the foreign language classroom. Teachers usually include activities that incorporate strategy work for learners, but no time is devoted in the class to explaining the application and practice of learning strategies into those particular language learning activities, and, what is worse, learners are not even aware of their existence.

\footnotetext{
${ }^{4}$ Principle 4: Creating opportunities for integration and explicitness.
} 
Concerning the third pedagogical principle, only two teachers create opportunities for cognitive autonomy support to some extent. Whenever possible, Teacher 1 encourages learners to justify or argue for their point and to evaluate their own and others' solutions or ideas (Stefanou et al., 2004), whereas we have also seen that Teacher 3 lets her students find their unique ways of problem solving when doing their learning activities. Yet, learners are not encouraged to engage in deep-level thinking whereby they could reflect critically on the beliefs they hold about themselves as learners and learning per se.

Motivation has been identified as one of the most important factors contributing to the success of FLL and the acquisition of learner autonomy (Spratt et al., 2002; Ushioda, 2003). Nonetheless, in the cases analysed we have observed that most teachers do not develop intrinsic motivation in the foreign language classroom. These teachers generally tend to create an atmosphere where learners are passive observers, tending towards boredom and disinterest in the lesson. Consequently, learners' commitment to learning decreases as their disaffection with the learning process increases. In contrast, other teachers (i.e. Teacher 1 , Teacher 5 and specially Teacher 6) do motivate their students by fostering student engagement in the learning process, developing a positive attitude towards learning and allowing learners to experience a sense of personal agency and self-determination. The result is immediately observed in the effort and concentration these learners put in the accomplishment of learning activities and the positive emotions (e.g. enthusiasm, interest and curiosity) they show during ongoing action.

Pedagogy for autonomy, as we previously pointed out, seeks to cater for the existing individual learner differences in the foreign language classroom. However, in the educational settings studied most learning situations are not open to learner differentiation. Teachers tend to impose a unified model of learning in which students with different learning abilities, interests and needs work on the same kind of learning activities and materials. In fact, only Teacher 6 provides opportunities for learner differentiation. On some occasions, the teacher organizes the class and the learning process so that different ways of learning can be put into practice at the same time. Learners can work according to their own particular needs and abilities in the target language by using materials at different levels of difficulty, pursuing something that is of their interest and being provided with a wide range of choices when selecting activities.

Only the teachers at the OLS develop an action-oriented approach to FLL. Teacher 6 encourages her learners to take a pro-active role in making informed decisions about their learning, whereas Teacher 5 implements an 'action-based teaching' (van Lier, 2007) based on the accomplishment of different language learning tasks which focus on the use of authentic language in real-world situations.

Fostering conversational interaction is the most common pedagogical principle in the cases studied. Learners are provided with opportunities to use the target language in the classroom and engage in meaningful interactions among themselves (either through pair work or group work) and with the teacher. Teachers encourage learners to engage in conversation to discuss relevant topics such as pollution or the need to protect the environment, and they prepare students to deal with real-world situations outside the classroom, for instance, making appointments, or asking for and giving directions. Only in two cases (i.e. Teacher 3 and Teacher 4) the target language is hardly used by students in the classroom. On these 
occasions classroom interactions are mainly aimed at correcting students' homework so learners' use of the language is simply reduced to a few words or just a sentence.

Finally, the notion of critical thinking included in the last pedagogical principle (i.e. promoting reflective inquiry) is a relevant goal for Teacher 1 and Teacher 2. In several classes devoted to Earth Day, learners are encouraged to discuss, think critically and argue coherently about topics of the greatest importance in our present-day society. This opportunity helps learners to develop the capacity for independent thought and judgement, whereby learners can explain, elaborate or defend their position on the topics free from any external pressure.

Summing up, learner autonomy and pedagogy for autonomy are far from being a relevant goal in the teaching practice of some of these foreign language teachers. In these cases teaching is viewed as simply a process of transmitting knowledge that students receive, store and digest passively. Many activities promoted in class still focus on lower-order thinking skills such as matching, filling gaps or labelling. Instead, we maintain that the target language must become the medium through which learners learn how to ask questions, pose problems, consider possible solutions, think creatively, and be more critical and independent as thinkers. The results of the study indicate that there is a definite need for teachers to go beyond the traditional view of education as "covering the curriculum" and "dispensing information" to actually enable learners to develop as autonomous, self-sufficient individuals.

The findings of the study contribute substantially to providing a picture of the current situation of the teaching practice in FLT, but further research is still needed to investigate why FLT is dominated by a traditional approach to language learning. The specialised literature, for example, has identified different variables which constrain the development of learner autonomy in language education such as examination syllabi (Coyle, 2003), the disempowering educational reforms and the absence of a collaborative culture of innovation in schools (Vieira, 2009), or the lack of teacher education programmes supporting the enactment of pedagogy for autonomy (Jiménez Raya, 2011), among others. Thus, the next step in this research would be examining the main reasons for the absence of learner autonomy in the foreign language classroom, that is, what possible obstacles or challenges prevent these particular teachers from fully implementing pedagogy for autonomy in their teaching.

\section{ConClusión}

Being aware that the results cannot be extrapolated to a wider educational context than those directly studied, the conclusion to be drawn from this research is that there is a striking lack of learner autonomy in the context of FLT. Concerning the educational contexts analysed, we can state that in the great majority of cases FLT is still dominated by a teacher-centred approach. The role of the teacher is perceived as central as he/she directs and controls everything that goes on in the classroom. As has been discussed previously, teachers typically shoulder most of the responsibility for the learning process and make all the decisions regarding language learning. Consequently, learners have no voice in the classroom and feel increasingly alienated from the learning process.

Due to the lack of learner autonomy predominating FLL, we have observed that learners are unable to make their own decisions concerning learning and, what is more, they tend to develop a state of complete dependence upon the teacher. In the long run, these learners 
will not be able to regulate their learning and develop the capacity for lifelong learning needed to adapt flexibly to the constant changes our present-day society is undergoing. For that reason, we advocate that the concept of learner autonomy needs to become a relevant educational goal not only in the theory (LOE, 2006) but also in the practice of FLT. In brief, it is absolutely necessary to create and implement learning programmes aimed at fostering learner autonomy in the Spanish educational system and breaking with this "culture of double talk" that Jiménez Raya (2011) pointed out.

To conclude, we would like to suggest different pedagogical implications for future action in the enactment of learner autonomy in the foreign language classroom. First of all, teachers need to let students assume greater responsibility for their learning since learners cannot become autonomous if they are not allowed to act autonomously. Learners need to experience personal agency, be able to take a pro-active role in making decisions concerned with their learning and plan, monitor and evaluate their own learning experiences. Moreover, teachers should provide learners with opportunities for learning to learn and self-regulation whereby they could develop the capacity to manage and take control over their learning processes through the use of different learning strategies which are explicitly taught in the classroom. Finally, it is essential for the achievement of learner autonomy that teachers build intrinsic motivation in their learners to keep them in the path of interest, curiosity and enthusiasm for learning.

It goes without saying that there is still a good way ahead to make learner autonomy a relevant educational goal in the practice of FLT. Hopefully, this paper can help to provide some directions for future action in the field.

\section{Acknowledgements}

I would like to thank Dr. Manuel Jiménez Raya for his supervision during the course of this research and the Spanish Ministry of Education for the research grant (FPU12/03899).

\section{REFERENCES}

Allwright, D. (1988). "Autonomy and individualization in whole-class instruction", in A. Brookes and P. Grundy (eds.), Individualization and Autonomy in Language Learning. London: Modern English Publications and the British Council, 35-44.

Aviram, A. (1993). "Personal autonomy and the flexible school", in International Review of Education, 5: 419-433.

Aviram, R. and Yonah, Y. (2004). "Flexible control: Towards a conception of personal autonomy for postmodern education", in Educational Philosophy and Theory, 36, 1: 3-17.

Benson, P. (2011). Teaching and Researching Autonomy in Language Learning. London: Longman. Camilleri Grima, A. (2007). "Pedagogy for autonomy, teachers' attitudes and institutional change: A case study", in M. Jiménez Raya and L. Sercu (eds.), Challenges in Teacher Development: Learner Autonomy and Intercultural Competence. Frankfurt: Peter Lang, 81-102.

Cohen, L., Manion, L. and Morrison, K. (2000). Research Methods in Education. London: Routledge.

Coyle, D. (2003). "Managing the differentiated classroom: Differentiation and learner autonomy", in M. Jiménez Raya and T. Lamb (eds.), Differentiation in the Modern Languages Classroom. Frankfurt: Peter Lang, 165-175. 
Dam, L. (1995). Learner Autonomy 3: From Theory to Classroom Practice. Dublin: Authentik.

Dam, L., and Legenhausen, L. (1996). "The acquisition of vocabulary in an autonomous learning environment- the first months of beginning English", in R. Pemberton, E.S.L. Li, W.W.F. Or and H.D. Pierson (eds.), Taking Control: Autonomy in Language Learning. Hong Kong: Hong Kong University Press, 265-280.

Dam, L., and Legenhausen, L. (2010). "Learners reflecting on learning: Testing versus evaluation in autonomous language learning”, in P. Paran and L. Sercu (eds.), Testing the Untestable in Language Education. Oxford: Multilingual Matters, 120-139.

European Commission. (2006). Key Competences for Lifelong Learning: A European Framework, available from http://ec.europa.eu/dgs/education_culture/publ/pdf/ll-learning/keycomp_en.pdf, accessed 12 April, 2012.

Holec, H. (1981). Autonomy and Foreign Language Learning. Oxford: Pergamon.

Jiménez Raya, M. (2008). "Learner autonomy as an educational goal in modern languages education", in M. Jiménez Raya and T. Lamb (eds.), Pedagogy for Autonomy in Language Education: Theory, Practice and Teacher Education. Dublin: Authentik, 3-15.

Jiménez Raya, M. (2009). "La autonomía como objetivo educativo: un estudio de las contradicciones y posibilidades de actuación en el aula de lenguas extranjeras", in F. Vieira, M.A. Moreira, J.L. Silva and M.C. Melo (eds.), Pedagogía para a Autonomía: (Re)Construir a Esperança na Educaçao. Braga: Universidad do Minho, 5-18.

Jiménez Raya, M. (2011). "Language learner autonomy in a Spanish context", in T. Trebbi and J. Miliander (eds.), Educational Policies and Language Learner Autonomy in Schools: A New Direction in Language Education? Dublin: Authentik, 67-80.

Jiménez Raya, M. and Pérez Fernández, J.M. (2002). "Learner autonomy and new technologies", in Educational Media International, 39, 1: 61-68.

Jiménez Raya, M., Lamb, T. and Vieira, F. (2007). Pedagogy for Autonomy in Language Education in Europe: Towards a Framework for Learner and Teacher Development. Dublin: Authentik.

Lamb, T. (2008). "Learner autonomy in eight European countries: Opportunities and tensions in education reform and language teaching policy", in M. Jiménez Raya and T. Lamb (eds.), Pedagogy for Autonomy in Language Education: Theory, Practice and Teacher Education. Dublin: Authentik, 36-57.

Legenhausen, L. (2003). "Second language acquisition in an autonomous learning environment", in D. Little, J. Ridley and E. Ushioda (eds.), Learner Autonomy in Foreign Language Classrooms: Teacher, Learner, Curriculum and Assessment. Dublin: Authentik, 65-77.

Little, D. (2007). "Language learner autonomy: Some fundamental considerations revisited", in Innovation in Language Learning and Teaching, 1, 1: 14-29.

Littlewood, W. (1997). "Self-access: Why do we want it and what can it do?", in P. Benson and P. Voller (eds.), Autonomy and Independence in Language Learning. London: Longman, 79-91.

Littlewood, W. (2002). "Cooperative and collaborative learning tasks as pathways towards autonomous interdependence", in P. Benson and S. Toogood (eds.), Learner Autonomy 7 : Challenge to Research and Practice. Dublin: Authentik, 29-40.

LOE (2006). Ley Orgánica de Educación 2/2006, de 3 de mayo [Organic Law 2/2006 of Education], available from http://www.boe.es/boe/dias/2006/05/04/pdfs/A17158-17207.pdf, accessed 5 May, 2012.

Macaro, E. (1997). Target Language, Collaborative Learning and Autonomy. Clevedon: Multilingual Matters.

Magno e Silva, W. (2008). "A model for the enhancement of autonomy”, in DELTA, 24: 469-492. 
Marsh, C., Richards, K. and Smith, P. (2001). "Autonomous learners and the learning society: Systematic perspectives on the practice of teaching in higher education", in Educational Philosophy and Theory, 33, 3: 381-395.

Morgan, J. (1996). "A defence of autonomy as an educational ideal", in Journal of Philosophy of Education, 30, 2: 239-252.

Nunan, D. (1997). "Designing and adapting materials to encourage learner autonomy", in P. Benson and P. Voller (eds.), Autonomy and Independence in Language Learning. London: Longman, 192-203.

Serrano Sampedro, I. (2008). "Fostering learner autonomy in a secondary school context", in M. Jiménez Raya and T. Lamb (eds.), Pedagogy for Autonomy in Language Education: Theory, Practice and Teacher Education. Dublin: Authentik, 126-142.

Smith, R.C. (2003). "Pedagogy for autonomy as (becoming-)appropriate methodology", in D. Palfreyman and R.C. Smith (eds.), Learner Autonomy across Cultures: Language Education Perspectives. Basingstoke: Palgrave Macmillan, 129-146.

Spratt, M., Humphrey, G. and Chan, V. (2002). "Autonomy and motivation: Which comes first?", in Language, Culture, and Curriculum, 15, 2: 106-116.

Stefanou, C.R., Perencevich, K.C., DiCintio, M. and Turner, J.C. (2004). "Supporting autonomy in the classroom: Ways teachers encourage student decision making and ownership", in Educational Psychologist, 39, 2: 97-110.

Trebbi, T., Arntzen, S., Danielsen, B. and Løhre, A. (2008). "Learner autonomy in the Norwegian foreign language classroom", in M. Jiménez Raya and T. Lamb (eds.), Pedagogy for Autonomy in Language Education: Theory, Practice and Teacher Education. Dublin: Authentik, 158-173.

Ushioda, E. (2003). "Motivation as a socially mediated process", in D. Little, J. Ridley and E. Ushioda (eds.), Learner Autonomy in Foreign Language Classrooms: Teacher, Learner, Curriculum and Assessment. Dublin: Authentik, 90-102.

Van Lier, L. (2007). "Action-based teaching, autonomy and identity", in Innovation in Language Learning and Teaching, 1, 1: 46-65.

Vieira, F. (2009). "Enhancing pedagogy for autonomy through learning communities: Making our dream come true?", in Innovation in Language Learning and Teaching, 3, 3: 269-282.

Wenden, A.L. (1986). "Incorporating learner training in the classroom", in System, 14, 3: 315-325. 